\title{
Policy Perspectives
}

Often, MEL includes a special section under the heading 'Policy Perspectives'. Papers here, often solicited ones, emphasise strategic policy implications rather than scientific rigour in a strict sense. Papers in Policy Perspectives are refereed by a lighter process that often results in speedier publication. Papers submitted to MEL are submitted for both sections at the discretion of the Editors. Authors not wishing to have their papers considered for Policy Perspectives should state this in the Cover Letter.

\section{Critical mass for the development of a new container port in Vlissingen}

\author{
Bart W. Wiegmans ${ }^{a, b, *}$, Rob Konings ${ }^{a, b}$ and Hugo Priemus \\ ${ }^{a}$ OTB Research Institute for Housing, Urban and Mobility Studies, TU Delft, \\ Delft, the Netherlands. \\ E-mail: b.wiegmans@tudelft.nl \\ ${ }^{\mathrm{b}}$ TRAIL Research School, Po Box 5017, 2600 GA DELFT, The Netherlands. \\ *Corresponding author.
}

\begin{abstract}
The economic importance of accommodating container transport and the increasing demand for container-handling capacity are major triggers for conventional ports to develop container terminals. The port of Vlissingen, located between Rotterdam and Antwerp, is aspiring to gain a position in deep-sea container handling. A relevant factor that greatly determines the potential of the port of Vlissingen is the critical mass of the container terminal handling operations to be developed by the port authority. In developing a full deep-sea terminal there is consensus about a critical mass of approximately one million TEU with possibilities to extend to at least two million TEU. In its role as a satellite port for Antwerp, a critical mass of 350000 TEU could be sufficient. In attracting sufficiently large container flows to Vlissingen, the competitive strength of the port plays an important role. Our contribution in this article lies in the analysis of the optimal size of container port development. The competitive position of the proposed container port of Vlissingen is analysed by using economic research and forecasting methods, backcasting analysis, and analysis of the competitive position vis-a-vis Antwerp and Rotterdam.
\end{abstract}

Maritime Economics \& Logistics (2009) 11, 399-417. doi:10.1057/mel.2009.14

Keywords: container terminal; container port; critical mass; Vlissingen

(C) 2009 Palgrave Macmillan 1479-2931 Maritime Economics \& Logistics Vol. 11, 4, 399-417 www.palgrave-journals.com/mel/ 


\section{Introduction}

The deep-sea container transport market has grown rapidly in the last decade and this growth is expected to continue over the coming years. Although the credit crisis of 2008 has caused an unexpected negative interruption, the deepsea container terminal handling capacity must grow in parallel with long-term economic growth in order to be able to accommodate the increasing container flows. Besides the well-known ports in the Hamburg/Le-Havre (HLH) range, such as Antwerp, Hamburg and Rotterdam, other ports also strive to capture a portion of this traffic in their deep-sea ports. One of the ports in the HLH range that currently does not handle deep-sea containers, but aspires to gain a position in the container terminal market, is the port of Vlissingen. Vlissingen is located between Rotterdam and Antwerp, on the banks of the Westerscheldt. The question of the critical mass plays an important role for the local and provincial governments in the development of the port. Container terminal handling capacity that might be accommodated in the port of Vlissingen depends - among other things - on the newly planned container terminal initiatives in existing deep-sea container ports. A relevant factor that determines the competitive position of the port of Vlissingen is the scale of the container terminal handling operations. This leads to the following central research question: Is there market potential to develop a deep-sea container port in Vlissingen and how to determine its critical mass? In addition to this introduction, this article first describes the HLH range, the existing container ports in the range and the port of Vlissingen in more detail. Second, the competitive position of the proposed container port of Vlissingen is analysed, using economic research and forecasting methods, backcasting analysis, and analysis of the competitive position vis-a-vis Antwerp and Rotterdam. Finally, some conclusions are drawn.

\section{Deep-sea Container Port Choice in a Competitive Environment}

\section{Deep-sea container port choice}

At company level of shipping lines, important policy decisions regarding service or product range, growth strategy, locations, company size, investments and purchase of production resources are taken. Among many decisions, the choice of location (port) and the purchase of production resources (container-handling services) are important. A number of issues have been earlier identified as 
Table 1: Deep-sea container port choice criteria

\begin{tabular}{|c|c|}
\hline Criterion & Indicator \\
\hline Availability of hinterland connections & $\begin{array}{l}\text { Road, railway, inland waterway and short sea } \\
\text { capacity in TEU/year }\end{array}$ \\
\hline $\begin{array}{l}\text { Accessibility of consumer markets } \\
\text { (large hinterland) }\end{array}$ & Number of consumers accessible in 1 hour \\
\hline Accommodation of large vessels & Minimal ship length in metres \\
\hline Maximum depth of port approaching route & Depth in metres \\
\hline Port infrastructure (state of the art) & Up-to-date infrastructure \\
\hline Availability of services & Number and type of services \\
\hline Port ship time (high productivity) & Total port ship time \\
\hline The degree of control of laws and legislation & Number of containers that is checked, plus duration \\
\hline $\begin{array}{l}\text { Number and frequencies of the deep-sea } \\
\text { line services }\end{array}$ & Number and frequency of deep-sea line services \\
\hline Reliability (absence of labour disputes) & Number and duration of labour conflicts in ports \\
\hline Certainty of fast and efficient handling & Number of false handlings \\
\hline $\begin{array}{l}\text { Absence of strong government intervention } \\
\text { with port management }\end{array}$ & Ownership of port authority and its implications \\
\hline Reasonable tariffs & Port harbour dues \\
\hline Degree of integration (EDI) & Not available \\
\hline Degree of congestion & Ship waiting time in minutes or hours \\
\hline Quality of the customs authorities settlement & Number and duration of problems at customs \\
\hline Port operating hours & $24 / 7 / 365$ \\
\hline Presence of related activity & Number and type of other businesses \\
\hline Tide dependence & Accessibility of the port, hours/day \\
\hline 'Reputation' of the port & Satisfactory ranking in benchmarking studies \\
\hline
\end{tabular}

Source: TU DELFT; OTB, 2007.

important in the container terminal literature. These include: (1) the optimisation of investments in container port development (Koh, 2001; Baird, 2006; Chou, 2007; Allahviranloo and Afandizadeh, 2008; Wiegmans et al, 2008); (2) the (technical) efficiency of container ports and liner vessels (Clark et al, 2004; Cullinane et al, 2006; Notteboom, 2007a); and (3) strategic developments in port systems (Notteboom, 1997; Van Klink and van den Berg, 1998; Wang and Slack, 2000; Song, 2002; Yap and Lam, 2006). From these, the criteria and indicators that influence deep-sea container port choice can be derived (see Table 1).

Besides deep-sea container port choice, container terminal selection is important. The selection of a container terminal differs markedly from the port selection problem. Both subjects are however closely related. An important issue in scientific research concerns the efficiency of container terminals. Stochastic Frontier Analysis and DEA analysis (Wiegmans et al, 2004) show that technical efficiency varies greatly among European container terminals. However, perhaps even more interesting is the analysis of the trade-off between obtaining terminal-handling capacity through either terminal

(C) 2009 Palgrave Macmillan 1479-2931 Maritime Economics \& Logistics Vol. 11, 4, 399-417 401 
Table 2: Criteria to invest in or purchase container-handling capacity

\begin{tabular}{ll}
\hline Criterion & Indicator \\
\hline Transhipment costs & Handling costs/TEU, storage costs/TEU \\
Speed & TEU/crane/hour \\
Reliability & Number of false handlings \\
Flexibility & Closing time delivery of containers \\
Maximum depth & Metres \\
Quay length & Metres \\
Immediacy of hinterland connections & Distance in metres of important connections \\
Congestion chance on the terminal & Number and duration of delays \\
Capacity & Maximum handling volume/year \\
\hline
\end{tabular}

Source: TU DELFT; OTB, 2007.

investment or purchase of handling capacity by a shipping line. In addition to strategic considerations, several aspects are important for this decision (Table 2).

\section{Deep-sea container ports in the HLH range}

In Northwest Europe, most deep-sea container ships call at three or four ports in the HLH range (MTBS, 2006). Often, one or two ports in the Benelux/France, one German and one British port are visited. This pattern reflects different geographical markets: (a) North-West Continent: the range between Le-Havre and Amsterdam, where the competition is mainly between Antwerp, Rotterdam and Zeebrugge (Amsterdam and Le-Havre take a less important position); (b) North-East Continent: the German ports (Bremerhaven and Hamburg); and (c) Great Britain and Ireland. The expectation is that for the very large deep-sea containerships (12000 + TEU) a limited number of ports in the HLH range will be called at. An important factor here is that fully laden large ships are not able to visit river (and canal) ports such as Antwerp, Hamburg and Amsterdam. The mainport strategy is not applied in extremis, where only one port in Northwestern Europe is called at, because distances, and thereby the costs of feeders and hinterland transport, become too long. This development was already foreseen 12 years ago by Notteboom (1997). In the past 10 years, an increase of between 3 and 12 per cent/year of container throughput has been observed per port (see Tables 3 and 4).

History has shown that the deep-sea container shipping market can change very quickly, and on account of this complexity it is very difficult to make accurate short-, or even long-term, predictions (Stopford, 1988).

402 (C) 2009 Palgrave Macmillan 1479-2931 Maritime Economics \& Logistics Vol. 11, 4, 399-417 


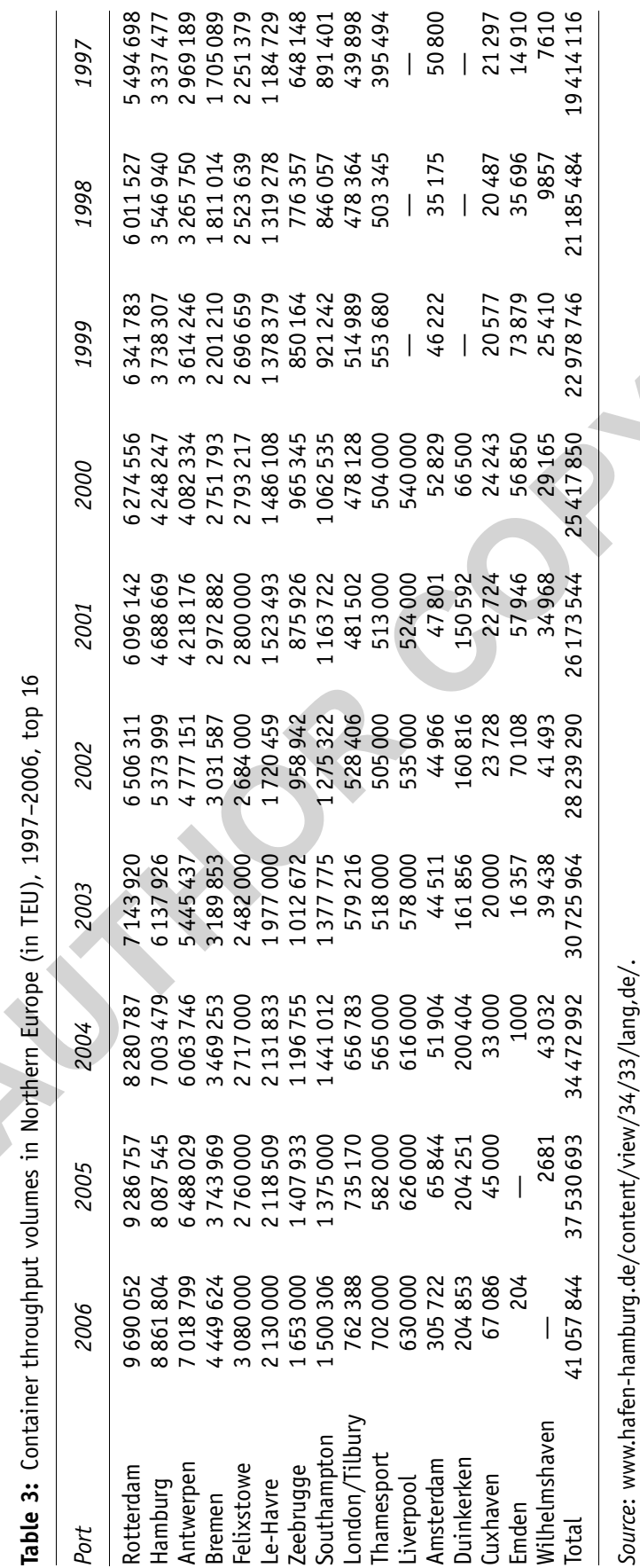




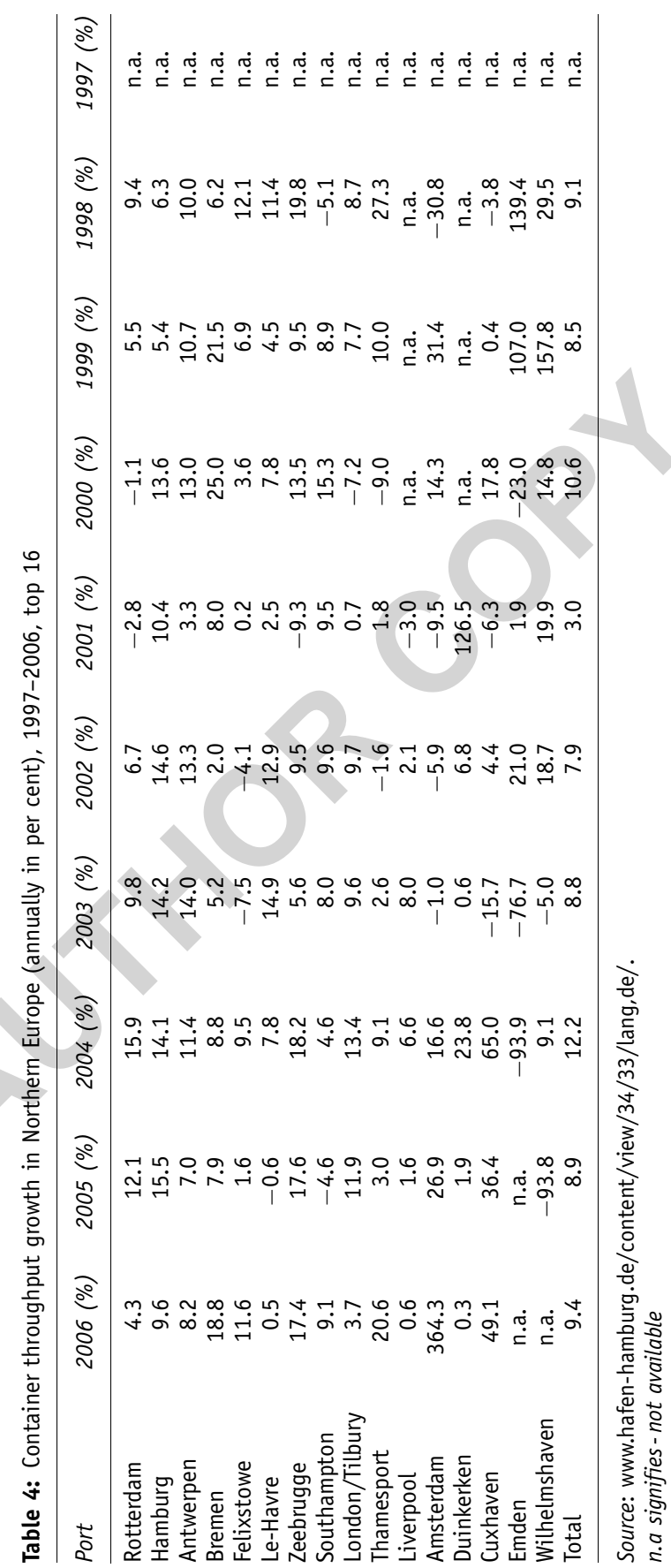


Table 5: Expected supply of throughput capacity in the HLH range (million TEU)

\begin{tabular}{lrrr}
\hline Port & Capacity 2007 & Capacity 2010 & Capacity 2020 \\
\hline Amsterdam & 1.2 & 1.2 & 1.2 \\
Antwerp & 12.0 & 15.5 & 15.5 \\
Bremerhaven & 6.0 & 6.0 & 6.0 \\
Hamburg & 9.9 & 13.5 & 13.5 \\
Le-Havre & 4.1 & 7.0 & 7.0 \\
Rotterdam & 11.0 & 12.5 & 19.5 \\
Zeebrugge & 2.0 & 3.0 & 3.0 \\
Wilhelmshaven & 0.0 & 2.7 & 2.7 \\
Vlissingen & 0.0 & 1.0 & 5.9 \\
Total & 46.2 & 60.7 & 72.3 \\
\hline
\end{tabular}

Source: TU DELFT; OTB, 2007.

Among others, CPB (2005) has indicated that in the long run, growth might abate because of a number of saturation mechanisms. Nevertheless, all ports expect continuous growth and they have plans to expand their capacity. Table 5 shows the development in throughput capacity of ports in the HLH range for 2010 and 2020, respectively, based on development plans that have already been agreed.

\section{Individual ports in the HLH range}

The most important container ports in the HLH range are (in alphabetical order) Amsterdam, Antwerp, Bremen, Hamburg, Le-Havre, Rotterdam and Zeebrugge. For Amsterdam, no container terminal capacity extension is yet expected, although a site has been reserved for an extension with two million TEU. Antwerp has increased its capacity considerably. Current capacity amounts to 12 million TEU and if the Deurganck Dok is entirely operational in 2010, then the total container terminal throughput capacity will amount to 15.5 million TEU. The Eurogate terminal in Bremen has a capacity of six million TEU and there are no plans for further capacity development. In Hamburg, four deep-sea container terminals operate with a joint capacity of approximately 9.4 million TEU. Space for further extension is limited and the maximum future capacity for Hamburg has been estimated at approximately 13.5 million TEU. Current capacity of Le-Havre amounts to approximately three million TEU. An extension is under way that will bring the capacity, in phases, up to 6.3 million TEU. In Rotterdam, extensions add up to a capacity increase from 8.6 million TEU in 2004 to 16 million TEU in 2014. Furthermore, an extension of the port area (Maasvlakte 2) is underway. In total, Maasvlakte 2 will bring the container capacity of Rotterdam up to a total of approximately 32 million TEU. In the port of Zeebrugge, current capacity can be extended to approximately three million TEU in 2020. In Wilhelmshaven, a new container port is also planned 
(JadeWeser port). The terminal, with a capacity of 2.7 million TEU, is expected to become operational in 2010 .

\section{A closer look at the port of Vlissingen}

The historical development of the port of Vlissingen has been strongly related to the industrial development of the port region. This fact is still visible in the profile of the port. The major types of goods handled are petroleum products, solid mineral fuels (coal) and transport equipment (cars). The total containerised cargo volume handled in 2007 amounted to 615000 tonnes. This corresponds to an estimated 70000 TEU, which was further transported by barge (70 per cent) and short sea shipping (30 per cent). Vlissingen recorded a total throughput of 19 million tonnes in 2007 and this makes the port the third largest port of the Netherlands. In the HLH-port range the market share of Vlissingen is about 2 per cent.

The interest to develop deep-sea container handling in Vlissingen has different backgrounds. First, it is related to the growing importance of the less traditional products handled in Vlissingen (neo-bulk sector including forest products, vegetables and fruits). In general, the cargo in this sector is increasingly containerised. Container-handling facilities in Vlissingen thus become a prerequisite for the port to remain an attractive link in the supply chain of these products. A second reason is a belief that the container-handling business itself will generate spinoffs through value added logistics and, hence, will also stimulate the regional economy. Of course the increasing demand for deepsea container-handling capacity in Northwest-Europe is evidently another encouraging factor.

At the moment, three development plans are underway to start container terminals in Vlissingen. The first project is the Scaldia Container Terminal, which is being developed as a joint venture between Sea-Invest and Zuidnatie. The terminal features a quay of $900 \mathrm{~m}$, with draft sufficient to accommodate container vessels of up to 7500 TEU. The final throughput capacity of this 60-ha facility is one million TEU. The terminal is under construction and will be launched with a capacity of 600000 TEU. The first vessels might already call in late 2009. Another development is the Verbrugge Container Terminal (VCT), which is the conversion of an existing breakbulk facility. VCT plans for a handling capacity of 2.9 million TEU per year. The terminal site will take up 125 ha of space. It is hoped that the first containers will be handled at VCT in 2011, but this depends on the speed with which various planning approvals can be obtained (Powell, 2008). The Western Scheldt Container Terminal (WCT) has a planned capacity of two million TEU, with a $2 \mathrm{~km}$ quay-wall and an area of 54 ha. It is believed that the terminal can start operations in 2012 at the earliest. 


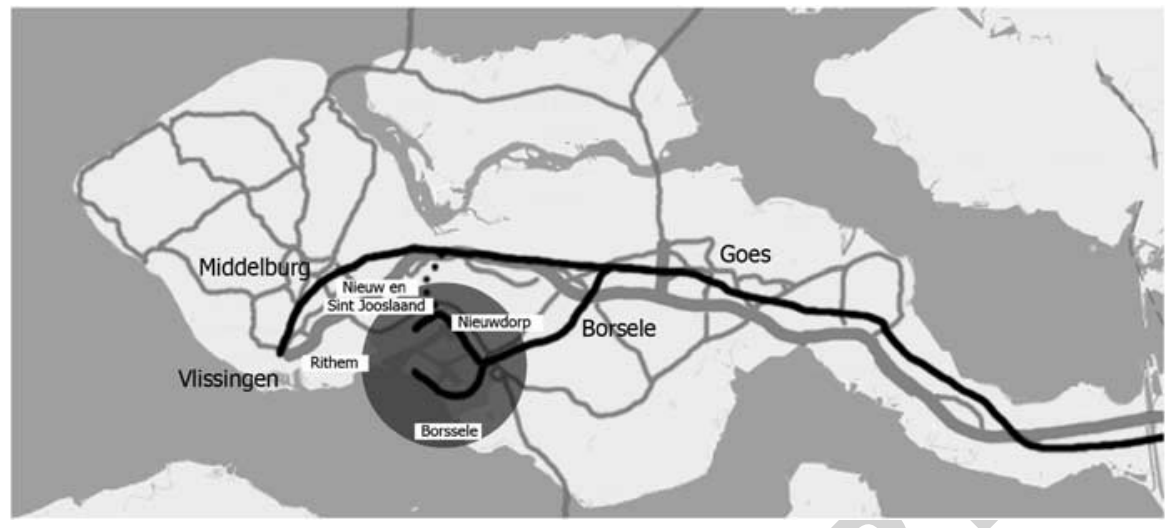

Figure 1: Overview of the position and accessibility of the port of Vlissingen. Source: Drawn by Itziar Lasa.

Geographically, the location of the port of Vlissingen has some interesting advantages. Its outward position nearby deep-sea shipping routes means a saving of about 7 hours sailing time compared to a visit at Antwerp. A draft of $14-16.5 \mathrm{~m}$ enables the port to receive the contemporary large vessels. Furthermore hinterland accessibility is a potential asset of Vlissingen. There are several options for hinterland transport and the hinterland routes are not yet confronted with heavy congestion in and around the port, such as in Antwerp, Rotterdam and Hamburg. From Vlissingen, there are several inland waterway routes to the hinterland: (i) towards Rotterdam, southern Netherlands and Germany; (ii) towards Antwerp and the rest of Belgium; and (iii) towards Zeeuwsch-Vlaanderen and further into Belgium. For road transport, there are two important traffic-routes: in an easterly direction the A58 (Vlissingen direction Bergen op Zoom) and in a southerly direction the N62 (to the Westerscheldetunnel and Belgium). For rail, the routes to the hinterland are the Sloelijn and the Zeeuwse line (from Goes to Roosendaal). At Roosendaal, connections to the north (direction Betuweline) and to the south (direction Antwerp) can be taken (See Figure 1 for an overview).

Comparative advantages of Vlissingen could be a significant stimulus for the development of a container port in Vlissingen. These 'pull' factors are important, but there may be also 'push' factors at hand in other container ports, such as a shortage of container-handling capacity or congestion. These circumstances could favour the development of Vlissingen, but are beyond its control. In this light it is relevant to look at future demand for containerhandling capacity in the region, but also at the critical mass that is needed in order to offer competitive services and attract container volumes to Vlissingen. This relation is discussed in the next section. 


\section{The Critical Mass for the Port of Vlissingen}

To assess the development potential of a deep-sea container port in Vlissingen, the critical mass of the container port needs to be analysed. In general, critical mass can be defined as the minimum size or amount of resources required to start a venture. In this case, it concerns the minimum size of the port of Vlissingen (from the port authority perspective) needed to develop itself as a container port. This minimum size is closely related to market demand forecasts. Several research methods exist for forecasting future demand: expert opinions, trend extrapolation, trend correlation, dynamic modelling, cross impact analysis, multiple scenarios, demand/hazard forecasting, comparative analysis, and back casting (Kotler, 1997). For the assessment of the critical mass of Vlissingen, a selection of these methods is used here. For this purpose, previous studies that have been carried out on the development potential of the port of Vlissingen are reviewed.

\section{Expert opinion}

In expert opinion, knowledgeable people are selected and asked to assign importance and probability scores to possible future developments. According to Notteboom (2004), Vlissingen should start with a container terminal throughput capacity of one million TEU, with the possibility to expand to two million TEU. Furthermore, two large deep-sea container operators would be required as customers, to be able to claim a serious role in the market. In addition to this, the port (Vlissingen) should guarantee extension options to deep-sea container operators (possibly by terminal participation) in order to link them to the port of Vlissingen in the long term. Another expert opinion originates from Hesse-NoordNatie (HNN). HNN (2004) describes conditions that determine the way in which a deep-sea container terminal in Vlissingen can successfully enter the market: (i) in the HLH range, the largest deep-sea container carriers generate on average of $360000-540000$ TEU per port. The largest alliances generate even more TEUs per port. HNN expects alliances to move over one million TEU per port by 2015; (ii) a minimum of two large customers is required; and (iii) a minimum quay length of $2000 \mathrm{~m}$ is required. Starting with a minimum of two large customers and an estimated throughput of 500000 up to one million TEU per customer per year, this adds up to a preferred starting capacity for a terminal of two million TEU.

According to Notteboom (2004), Vlissingen could also act as the portal for Antwerp. Direct shuttles between Vlissingen and Antwerp would link Vlissingen to the hinterland connections of Antwerp. In this scenario, the port could start with a lower capacity. For an inland waterway shuttle (frequency 
of six sailings/week with barges of 200 TEU) about 100000 TEU per year is necessary. For a similar rail shuttle (with a capacity of 80 TEU) about 40000 TEU is necessary. Given a likely modal split of 50 per cent inland waterway and rail; 35 per cent road; and 15 per cent transhipment, this results in a total of about 280000 TEU. Adding road containers with local origin and destination, the total volume reaches 350000 TEU.

In another study, which focussed on the importance of the quality of hinterland transport, a minimum throughput of about 900000 TEU was estimated as the volume needed to offer deep-sea container carriers an acceptable quality in hinterland and feeder transport (Ecorys, 2004). The assumptions regarding an acceptable quality of hinterland transport were as follows: a daily rail service in two directions (eastbound to Germany and southbound to Belgium and France), 10 times per week barge sailings to Rhine river terminals (in Germany), 10 barge sailings per week to Rotterdam and Antwerp, and 15 weekly short sea shipping services to several regions, including five services to ports in the United Kingdom. Although the number of experts consulted was limited, there seems to be consensus on the critical mass of a full deep-sea container terminal: at least one million TEU. This capacity would be desirable from a commercial perspective to operate a terminal, but would also be promising from the perspective of hinterland transport quality.

\section{Trend extrapolation}

In trend extrapolation, researchers fit curves through past time series to make forecasts. This can be quite unreliable, as new developments can change future development paths dramatically. In the HLH-region, a total deep-sea containerhandling capacity of approximately 60 million TEUs will be available in 2010 . This seems sufficient to satisfy the demand of the region. This holds for growth scenarios that range from 4 to almost 8 per cent throughput growth per year. For the period up to 2020, the total planned container terminal capacity seems to assume an expected market growth of around 4.5 per cent per year. The current and planned container terminal capacity seems well-positioned to accommodate this growth; however, should the increase be larger (6-8 per cent or more), then extra capacity might be needed. In the case of the port of Vlissingen, this method has been used to argue that the expected growth in the HLH range in handling capacity is not sufficient and that this offers opportunities for the port of Vlissingen to enter the container-handling market. This argument is valid in the case of high market growth (6-8 per cent) combined with the assumption that the other existing container ports do not react to higher market growth.

(C) 2009 Palgrave Macmillan 1479-2931 Maritime Economics \& Logistics Vol. 11, 4, 399-417 409 


\section{Dynamic modelling}

In dynamic modelling, researchers build sets of equations that describe the underlying system often based on assumptions. Model analysis has been used to calculate the market position of WCT based on its specific maritime accessibility qualities and the qualities of the hinterland transport (Ecorys, 2006). In 2020, according to the most unfavourable scenario, WCT will be able to attract a throughput of almost 1.5 million TEU, and according to the most favourable scenario, approximately 2.6 million TEU (CPB, 2006a, b and Ecorys, 2006). In this analysis, the competitive strengths of the port of Vlissingen are explicitly incorporated. The estimated throughput volumes do not really reflect critical mass, but they rather serve as the basis for the assessment of the critical mass that should be developed.

\section{Comparative analysis}

A (historical) comparison of comparable container port developments might also indicate the critical mass for the port of Vlissingen. From Table 6, a number of conclusions can be drawn. First, it seems that container port initiatives that put large handling quantities on the market and built upon huge market prospects are able or will be able to prosper (Tanjung Pelepas, Punta Colonet and Tanger). Relatively smaller container port initiatives (with relatively smaller handling capacities put on the market) and with limited extension possibilities (Zeebrugge, Amsterdam, Vlissingen) have more problems in trying to become successful, although Zeebrugge, after many years of stagnation, seems to have reached a breakthrough.

It is also worthwhile to note that the scale of individual concessions of deep-sea container terminals has increased considerably in the last decades. Notteboom (2007b) observed in the Rhine-Scheldt-Delta ports (Zeebrugge, Vlissingen, Antwerp, Rotterdam and Amsterdam) that the size of terminals opened in the 1990s ranged between 0.5 and one million TEU capacity, while since 2004 all new terminal concessions had at least two million TEU capacity. This actual development corresponds well with the experts' opinion.

\section{Backcasting}

Backcasting is a method in which the desired (by the port authority) future conditions are envisioned and steps are then defined to attain those conditions, rather than taking steps forward that are merely a continuation of present methods extrapolated into the future (Holmberg and Robèrt, 2000). Such an approach could also be used to estimate the critical mass for container handling 


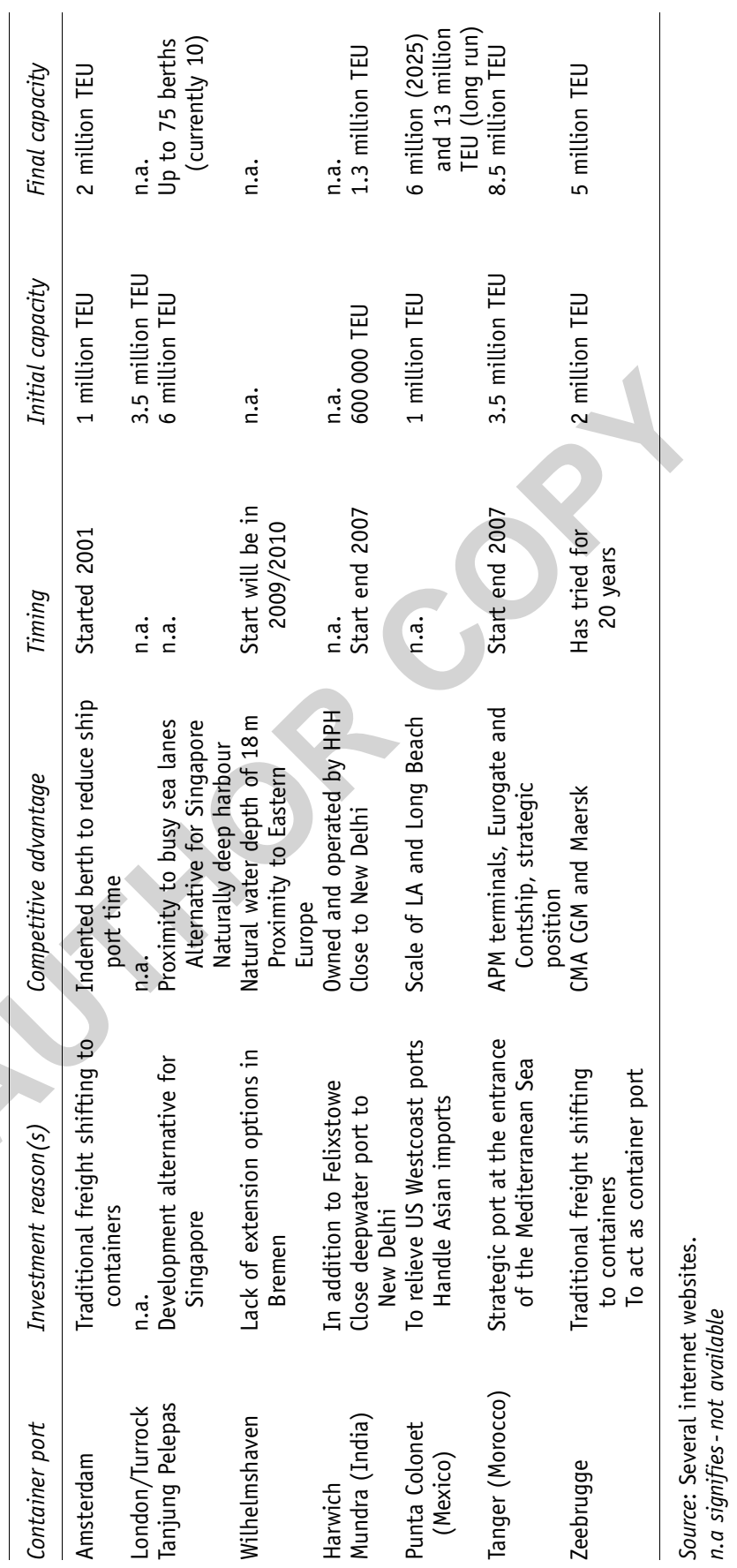




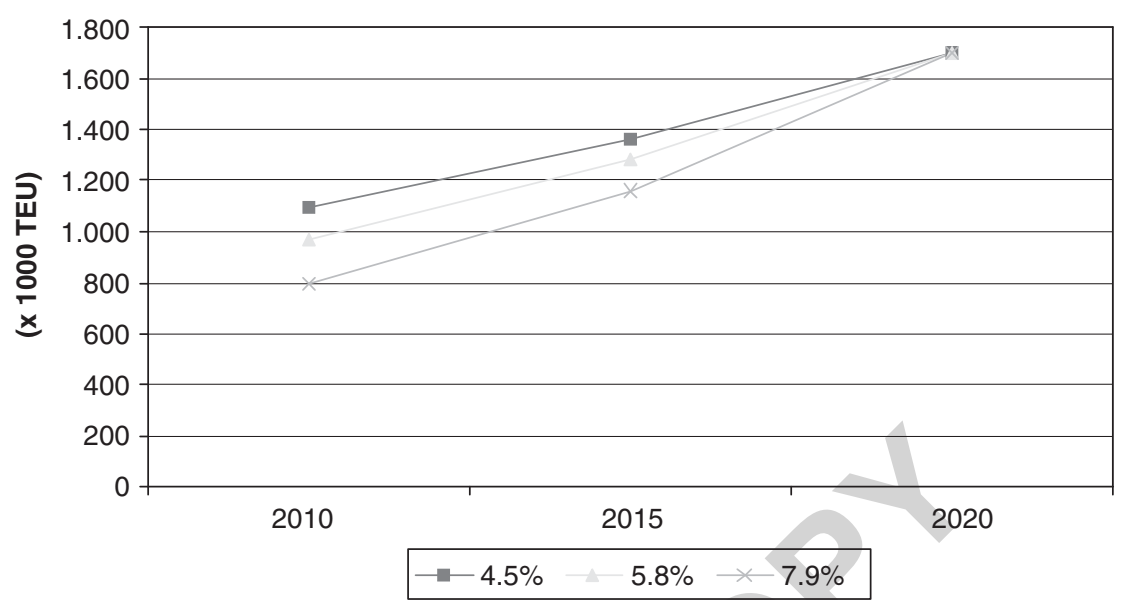

Figure 2: Backcasting scenarios WCT. Source: TU DELFT; OTB (2007).

in Vlissingen. In this case, the critical mass is defined as the minimum required container throughput in 2010, in order to have a desired 85 per cent occupancy rate of the maximum planned capacity of the three terminal initiatives for the year 2020. Different scenarios for the growth of deep-sea container transport in the HLH range serve as the basis for the 'feedback' of throughput volume to reach the minimum required container terminal throughput in 2010. These scenarios, 4.5, 5.8 and 7.9 per cent annual growth, have been based on the long-term forecasts of Ocean Shipping Consultants (OSC) (2004), ISL (2006), CPB (2006a) and HWWI (2006) and cover the range from the most pessimistic to the most optimistic forecasts. For the WCT, a maximum capacity of two million TEU is planned. Based on an 85 per cent utilisation rate (corresponding with a critical mass of 1.7 million TEU) and growth scenarios ranging from 4.5 to 7.9 per cent, the starting volume should be between 800000 and 1.1 million TEU in 2010 (TU DELFT; OTB, 2007) (see Figure 2).

The final capacity of VCT is estimated at 2.9 million TEU. Based on an occupancy rate of 85 per cent (corresponding with a throughput of 2.5 million) and the three growth scenarios, the starting volume for the VCT should be between 1.1 and 1.6 million TEU (see Figure 3).

The capacity of the Scaldia Container Terminal is planned at 1000000 TEU. The starting volume for this terminal should be between 400000 and 550000 TEU (see Figure 4). If the throughput is taken as $850000 \mathrm{TEU}$, it means that the starting volume must be between 400000 and 550000 TEU.

If all terminal initiatives in the port of Vlissingen are developed at the same time, the starting volume would have to range between 2.3 and 3.2 million TEU 


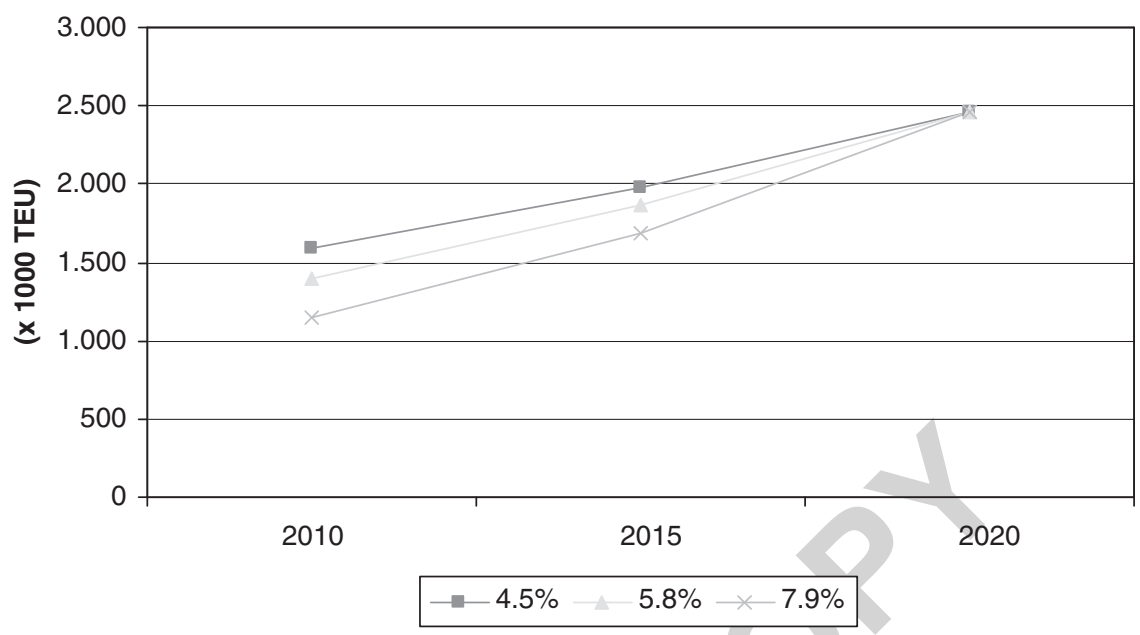

Figure 3: Backcasting scenarios VCT. Source: TU DELFT; OTB (2007).

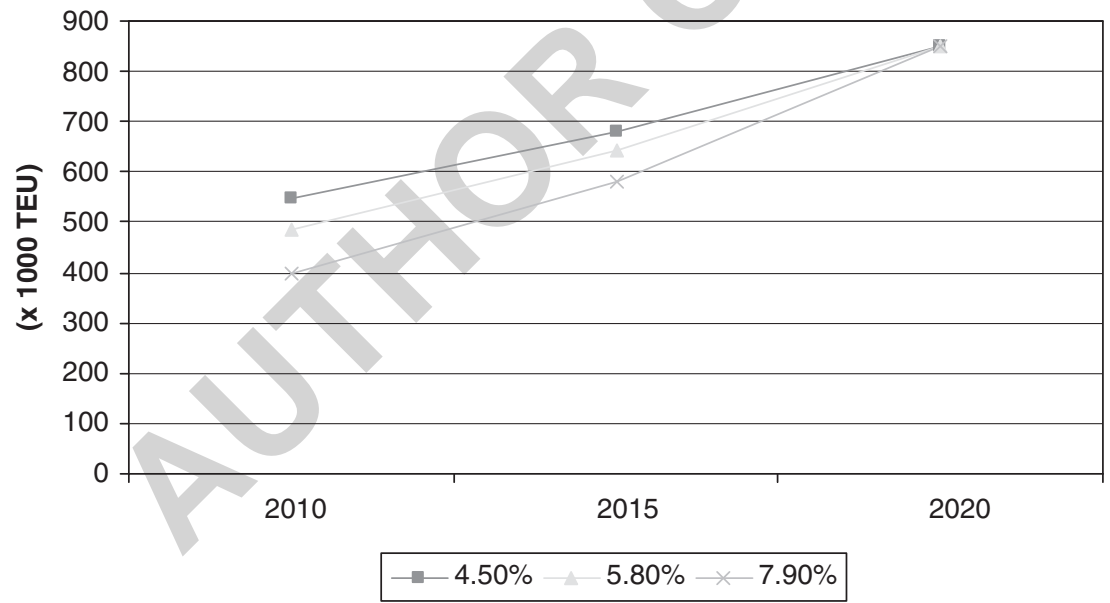

Figure 4: Backcasting scenarios Scaldia Container Terminal.

Source: TU DELFT; OTB (2007).

(see Figure 5). Total capacity would be 5.9 million TEU and the throughput would amount to 5.0 million TEU. To realise such a large volume seems an ambitious goal given the current position of the port of Vlissingen. However, if two deep-sea container carriers could be involved in the investment phase, and both guarantee approximately 1.5 million TEU, a large critical mass for the port of Vlissingen could be achievable. In the current economic situation, the 


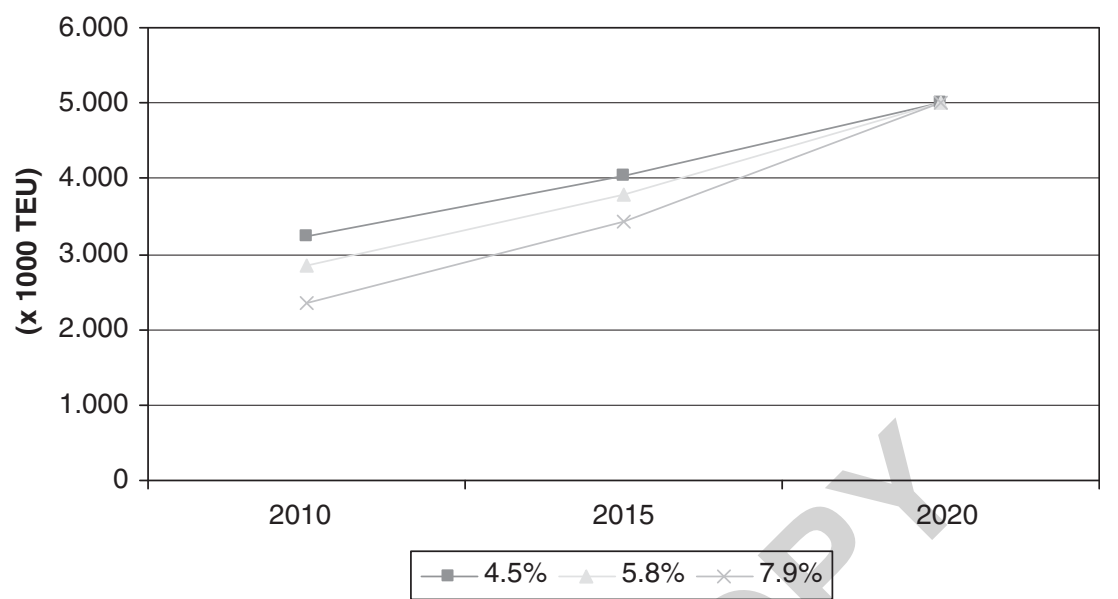

Figure 5: Backcasting scenarios all terminals in the port of Vlissingen. Source: TU DELFT; OTB (2007).

deep-sea carriers have plenty of capacity and therefore will not decide to direct such large volumes to the new container port of Vlissingen.

The backcasting approach gives an indication of current container-handling volumes that are required to achieve an aspired handling volume in the future, given certain growth path developments. It should be stressed that the assumed growth paths in this analysis are determined exogenously, that is, based on general long-term growth expectations in the HLH region. Consequently, this backcasting method is also a rather one-dimensional approach.

Comparing the different research methods, one sees that there is coherence in their results. The starting capacity for a deep-sea container port is approximately one million TEU, with possibilities for extension to two million TEU. Preferably there should be further possibilities for extension available. The critical mass is also important for the quality of the hinterland connections, in particular for the development of intermodal transport. The frequency and quality of hinterland connections depend on container throughput. It is estimated that approximately 900000 TEU should be handled in order to enable the development of rail, barge and short sea shipping services of sufficient quality. In its role as a satellite port for the port of Antwerp, in which hinterland transport services are connected by barge and rail shuttle services to the hinterland transport services of Antwerp, a handling volume of 300 000-350 000 TEU in the port of Vlissingen could be sufficient.

In this exploration of critical mass, the focus has been primary on factors that influence the minimum scale of operations. However, it should be stressed that supply-related factors play a role as well. At terminal level, the financial 
and operational performance of the terminal comes in to play in decisions on the scale of operations. Volume handled should be sufficiently large to justify the required investments. On the other hand, the existence of (dis)economies of scale may be a determinant in choosing the scale of operations. These issues, however, have not been adequately addressed in scientific literature. In a study of OSC (2004), the critical mass to develop a terminal from a financial-economic perspective is estimated at 300000-400000 TEU. It is interesting to note that OSC states that the position of the terminal in the network plays a role, that is, a stand-alone terminal or an agglomeration of terminals. This observation is also supported by the findings of Vanelslander (2006). In addition to the existence of scale economies in terminal capacity, the author shows the positive impact of networks and cooperation agreements on the operational costs of terminals. The results of these two studies actually underline that the critical mass of Vlissingen may also depend on the institutional framework in which a container port will be developed, that is the possible involvement of actors in the port of Rotterdam or Antwerp.

\section{Conclusions}

The main issues explored in this article are as follows: Is there market potential to develop a deep-sea container port in Vlissingen and how to determine its critical mass? If deep-sea container carriers would consider calling at Vlissingen, what would be the minimum required scale to start and develop container terminal handling successfully? This research question has been approached through a review of different research studies on the potential demand for container handling in the port of Vlissingen.

The best way to analyse the critical mass issue is by using scientifically reliable research and forecasting methods. Overall, the scientific basis of most estimates of the critical mass of Vlissingen remains thin. On the other hand, it is difficult (and maybe even impossible) to accurately and reliably estimate the critical mass of a port. Summarising the used methods, two options result for the development of the port of Vlissingen: (1) a large-scale alternative and (2) a small-scale alternative. In the former case, there is consensus on a critical mass of approximately one million TEU, with extension possibilities to at least two million TEU. The small-scale alternative is based on a critical mass of approximately 350000 TEU, based on hinterland and feeder connections, or as a sort of satellite port for Antwerp.

The backcasting method applied to the current terminal plans led to a container-handling throughput of about 400000-550000 TEU for the Scaldia Container terminal, 1.1-1.6 million TEU for the VCT and 0.8-1.1 million TEU

(C) 2009 Palgrave Macmillan 1479-2931 Maritime Economics \& Logistics Vol. 11, 4, 399-417 415 
for the WCT. These results roughly correspond to the identified options in other studies on the small- and large-scale options.

The critical mass in Vlissingen is influenced by the expected growth in the HLH range, and by the terminal throughput capacity developments in competing deep-sea container ports. Overall, after 2010, with continuing growth and no new large terminal investment plans in other container ports, there might be a perspective for Vlissingen. Geographically the port has advantages, which could place it at a promising position, to complement the well-established neighbouring ports, that is Antwerp and Rotterdam. The decision to develop Vlissingen as a container port (or not) is - in the end - an investment decision determined by market forces. The circumstances of the port of Vlissingen to enter the container-handling market can be optimised through a dedicated strategy, but that does not guarantee success. Three optimisation strategies can be identified: (i) concentrate on the proposed buyers (carriers) of the container-handling service and try to develop close customer-supplier relationships in order to secure them as customers of Vlissingen. In this respect, both the timing of Vlissingen's proposed market entry, and the expiration of contracts that competing ports have with deep-sea container carriers are very important; (ii) control the buying decisions of the deep-sea container carriers, to be able to influence these decisions in a positive way for the port of Vlissingen. Decisions are increasingly taken in the head offices of the deep-sea carriers. This means that the board of directors of the port of Vlissingen should meet with the boards of the different deep-sea carriers; and (iii) develop the selling capabilities of the port authority of Vlissingen (Zeeland Seaports) to be able to match the buying capabilities of the deep-sea container operators and together develop a deal that is beneficial for both sides.

\section{References}

Allahviranloo, M. and Afandizadeh, S. (2008) Investment optimisation on port's development by fuzzy integer programming. European Journal of Operational Research 186: 423-434.

Baird, A.J. (2006) Optimising the container transhipment hub location in northern Europe. Journal of Transport Geography 14: 195-214.

Chou, C.C. (2007) A fuzzy MCDM method for solving marine transhipment container port selection problems. Applied Materials and Computation 186: 435-444.

Clark, X., Dollar, D. and Micco, A. (2004) Port efficiency, transport costs and bilateral trade. Journal of Development Economics 75: 417-450.

CPB. (2005) Verruiming van de vaarweg van de Schelde. Den Haag, the Netherlands: CPB.

CPB. (2006a) Aanpassing WLO scenario's voor het containervervoer, CPB Memorandum, opgesteld in samenwerking met AVV. Den Haag, the Netherlands: Kennisinstituut voor Mobiliteitsbeleid.

CPB. (2006b) Maatschappelijke kosten-batenanalyse van de Westerschelde Containerterminal, een second-opinion. Den Haag, the Netherlands: CPB Notitie.

416 (C) 2009 Palgrave Macmillan 1479-2931 Maritime Economics \& Logistics Vol. 11, 4, 399-417 
Cullinane, K., Wang, T.-F., Song, D.-W. and Ping, J. (2006) The technical efficiency of container ports: Comparing data envelopment analysis and stochastic frontier analysis. Transportation Research Part A 40: 354-374.

Ecorys. (2004) Ontwikkelingsalternatieven van de Zeeuwse havens, Eindrapport. Rotterdam, the Netherlands: Ecorys.

Ecorys. (2006) Maatschappelijke Kosten-Baten Analyse Westerschelde Container Terminal, Eindrapport. Rotterdam, the Netherlands: Ecorys.

HNN (Hesse-NoordNatie). (2004) Minimale schaal Westerschelde Container Terminal. in: FTT Procesontwikkeling, Advies over de voortgang van het WCT dossier, voorlopig eindrapport, Delft, juli.

Holmberg, J. and Robèrt, K.H. (2000) Backcasting from non-overlapping sustainability principles: A framework for strategic planning. International Journal of Sustainable Development and World Ecology 74: 291-308.

HWWI (Hamburgisches Weltwirtschaftliches Institut). (2006) Maritime Wirtschaft und Transportlogistik, Band A: Perspectiven des maritime Handelsfrachtschiffahrt und hafenwirtschaft. Hamburg, Germany: HWWI.

ISL (Institut für Seeverkehrswirtschaft und Logistik). (2006) Developments and trends in the container shipping market. Presentatie van B. Lempert at the ERIM Research Seminar Developments \& Trends in Maritime Logistics; 21 Februari, Erasmus Universiteit Rotterdam.

Koh, Y.-K. (2001) Optimal investment priority in container port development. Maritime Policy and Management 28: 109-123.

Kotler, P. (1997) Marketing Management; Analysis, Planning, Implementation, and Control. Upper Saddle River, NJ: Prentice Hall International.

MTBS (Maritime \& Transport Business Solutions). (2006) Marktpositie WCT. Rapport in opdracht van ESM, Rotterdam.

Notteboom, T.E. (1997) Concentration and load centre development in the European container port system. Journal of Transport Geography 5(2): 99-115.

Notteboom, T.E. (2004) WCT - Extern advies. in: FTT Procesontwikkeling, Advies over de voortgang van het WCT dossier, aanvullingen op het voorlopige eindrapport, Delft, 31 augustus.

Notteboom, T.E. (2007a) Spatial dynamics in the container load centres of the Le Havre-Hamburg range. Zeitschrift für Wirtschaftsgeographie 51: 108-123.

Notteboom, T.E. (2007b) Concession agreements and port performance in an era of global terminal operators. In: P. Hilferink (ed.) Proceedings of the BIVEC-GIBET Research Day, e.a., Zelzate, Belgium: Nautilus, pp. 339-348.

OSC (Ocean Shipping Consultants). (2004) WCT Vlissingen - an update analysis. May, Chertsey, Surrey, UK.

Powell, A. (2008) Small players muscling in. Cargo Systems June, 39: 41.

Song, D.-W. (2002) Regional container port competition and co-operation: The case of Hong Kong and South China. Journal of Transport Geography 10: 99-110.

Stopford, M. (1988) Maritime Economics. London: Unwin Hyman.

TU DELFT; OTB. (2007) Quick-scan; de terminalkeuze van reders. Delft: TU Delft, OTB.

Vanelslander, T. (2006) Cooperation in container handling: What are the effects of economies of scale? Proceedings of the European Transport Conference, Strasbourg.

Van Klink, H.A. and van den Berg, G.C. (1998) Gateways and intermodalism. Journal of Transport Geography 6(1): 1-9.

Wang, J.J. and Slack, B. (2000) The evolution of a regional container port system: The Pearl River Delta. Journal of Transport Geography 8: 263-275.

Wiegmans, B.W., van der Hoest, A. and Notteboom, T.E. (2008) Port and terminal selection by deep-sea container operators. Maritime Policy and Management 35(4): 517-534.

Wiegmans, B.W., Rietveld, P., Pels, E. and Van Woudenberg, S. (2004) Container terminals and utilisation of facilities. International Journal of Transport Economics XXXI: 313-339.

Yap, W.Y. and Lam, J.S.L. (2006) Competition dynamics between container ports in East Asia. Transportation Research Part A 40: 35-51. 